\title{
Pharmaceutical Price Controls and Entry Strategies
}

\author{
Margaret K. Kyle*
}

March 9, 2005

\begin{abstract}
This paper examines the use of price controls on pharmaceuticals, while controlling for both market structure and of firm (and product) characteristics, in estimating the extent and timing of the launch of new drugs around the world. Price controls are found to have a statistically and quantitatively important effect on pharmaceutical launches. These effects take two forms. First, drugs invented by firms headquartered in countries that use price controls reach fewer markets and with longer delays than products that originate in countries without price controls. Second, companies delay launch into price-controlled markets, and are less likely to introduce their products in additional markets after entering a country with low prices. Launches into low price countries in Europe are further delayed after a regulatory change allowing parallel imports, which could potentially depress prices in high price markets. Overall, the results suggest that a country's use of price controls not only has a substantial impact on entry into that market, but into other countries as well, and may affect the strategies of domestic firms.
\end{abstract}




\section{Introduction}

This paper examines the use of price controls on pharmaceuticals, while controlling for both market structure and firm and product characteristics, in estimating the extent and timing of the launch of new drugs around the world. The influence of regulation on launch decisions has been highlighted by many economists (most recently, Djankov, La Porta, Lopez-de-Silanes, and Schleifer (2002)). This work examines how such regulations affect not only the country that uses them, but also the domestic industry and entry into other markets.

Pharmaceutical markets provide an interesting empirical puzzle to explore. Developed nations differ from each other in the number of drugs that compete in a market as well as in the mix of available products. Over the past 20 years the US has had an average of three drugs (unique chemical entities) per therapeutic class, or medical condition for which a drug is prescribed. Italy, with a population of about 57 million, has an average of five drugs per therapeutic class. Switzerland has an average of four drugs per class for a population of just 7 million. Only one-third of the prescription pharmaceuticals marketed in one of the seven largest drug markets (the US, Japan, Germany, France, Italy, the UK, and Canada) are also marketed in the other six. This is a strikingly low figure given the size and wealth of these countries and the substantial trade between them, and since pharmaceutical firms should have incentive to spread the large sunk costs of drug development over as many markets as possible. In addition, some markets have no entrants at all, despite the availability of treatments in other countries.

The entry patterns of pharmaceuticals are important to understand for several reasons. The cost of untreated conditions in markets with no entry may be substantial. In addition, there are many monopoly and duopoly markets. Competition usually results in lower prices, and given the widespread concern about the cost of pharmaceuticals, it is valuable to know what impedes further entry into a market. This study also contributes to the debate on the effect of regulations, particularly price controls, by examining their impact on the market structure of pharmaceutical 
markets within a country and on the strategies of firms headquartered in regulated countries. These issues are especially salient as several state governments in the US, as well as the federal government, have implemented or are considering the use of price controls to contain expenditures on pharmaceuticals, and there are proposals to allow imports of price-controlled drugs from Canada. In addition, the European Union has recently expanded and is expected to continue to add member states. This paper provides some predictions on how this expansion could affect the prices and availability of drugs in the rest of the trading bloc.

Price controls are found to have a statistically and quantitatively important effect on pharmaceutical launches. Drugs invented by firms headquartered in countries that use price controls reach fewer markets and with longer delays than products that originate in countries without price controls. Possible explanations for this result are discussed below. In addition, companies delay launch into price-controlled markets, and are less likely to introduce their products in additional markets after entering a country with price controls. Overall, the results suggest that a country's use of price controls not only has a substantial impact on entry into that market, but into other countries as well.

The following section gives a brief overview of the pharmaceutical industry and outlines regulatory regimes in the countries included in this study. Section III describes the expected impact of price regulation on product launch decisions. The empirical model is explained in Section IV, and Section V describes the data used in this research. Results are presented in Section VI, and Section VII concludes.

\section{Description of Industry and Regulatory Regimes}

Expenditures on health care range from 5\% of GDP in South Korea to over 13\% in the US, and the share of pharmaceutical sales in total health expenditures account for anywhere from $4 \%$ in the US to nearly $18 \%$ in France and Italy. The US is the largest single market at $\$ 97$ billion of annual revenue; the five largest European markets amount to $\$ 51$ billion, as does 
Japan. ${ }^{1}$ The industry is highly fragmented: there are thousands of small firms around the world, only several hundred of which are research-based and have brought at least one drug to market. Table 1 presents a crosstabulation showing the number of drugs by country of origin (location of the inventing firm's headquarters) with the countries in which those drugs are launched. The US is the origin of over a quarter of all drugs, and these products reach an average of about nine markets. Though many drugs are invented in Japan and Italy, they are launched in fewer foreign markets. Drugs with small domestic markets like Denmark, Switzerland, and the Netherlands spread to more foreign markets than drugs with large home markets.

National markets for pharmaceuticals differ on a number of dimensions, of which regulation is perhaps the most notable. The entry of pharmaceuticals is restricted and in many countries, so is the price. Each nation has an agency or ministry devoted to pharmaceutical evaluation, which have heterogeneous standards for establishing safety and efficacy and which vary in how quickly they evaluate new drug applications. Some require that some clinical trials be performed on domestic patients and are less accepting of foreign data. Some European countries require proof of cost-effectiveness. During the 1990s, mean approval times ranged from 1.3 years in France for 1990, to 4.8 years in Spain for $1991 .^{2}$ In addition to differences in agency funding and bureaucratic efficiency, the number of drugs under review varies considerably across years and countries. There has been a gradual move towards harmonization of regulatory standards for all major markets, particularly within the European Union. Under the EU's Mutual Recognition Procedure, enacted in 1995, a drug approved in one member state (the Reference Member State) must be granted marketing authorization in other member states (the Concerned Member States) within two months unless a Concerned Member State objects through a formal process. Another option is the Centralized Procedure, in which a drug is submitted to the European Medicines Evaluation Agency for marketing approval in all EU nations. However, the drug's manufacturer must still negotiate with individual countries over price under either the Mutual Recognition Procedure or the Centralized Procedure. 
Price regulation has many variants (see Table 2). Most countries have adopted some form over the last thirty years or so. As the term is used in this paper, price controls refer a cap on either the ex-manufacturer price or the amount a national health service pays for a pharmaceutical product (the reimbursement price). The price for a drug is officially based on some determination of therapeutic value, the cost of comparable treatments, the contribution of the drug's manufacturer to the domestic economy, and manufacturing cost; the weight given to each factor differs by country. Importantly, a number of countries reference the price of a drug in other countries when setting price. This "international reference pricing" means that the price in one country can affect the price in other markets. Negotiations between pharmaceutical firms and national governments may be lengthy and tense, and drug companies often blame this process for delays in product launch. Pfizer chairman Hank McKinnell has stated "[w]e introduce our new products later and later on the French market, and if the government continues to put pressure on prices, there will be no more [new products]." ${ }^{3}$ Broadly speaking, northern European countries and the US have fewer or less intrusive price controls, while southern Europe has more extensive government intervention. ${ }^{4}$ The price of a medication tends to be significantly lower in countries using price controls than in countries which do not (Danzon and Chao, 2000a). During the 1990s, many countries also enacted price freezes or mandatory price cuts in response to the increasing cost of pharmaceuticals.

Some countries use demand-side controls instead of, or in addition to, direct control of price. Typically, demand-side controls involve either a cap on the total cost of drugs a physician can prescribe (encouraging doctors to prescribe less expensive products) or a reference-pricing scheme, in which the patient is responsible for paying the price difference between his chosen drugs and a reference drug defined by the government. Several governments (in South Korea, Mexico, Spain, and the UK) regulate the profits of pharmaceutical firms on drugs sold in these countries. The government negotiates with manufacturers and sets a rate of return according to 
complicated formulas accounting for operating costs, promotion expenditures, and $\mathrm{R} \& \mathrm{D}$ spending.

Countries also differ in subtle non-regulatory aspects. The number and size of pharmacies are highly varied across countries, as are distribution and dispensing margins. Physicians have diverse prescribing habits; in Japan, physicians both prescribe and dispense drugs, and they tend to prescribe lower doses than elsewhere in the world and combinations of drug therapies. Consumer compliance and trust of doctors is multifarious. Over-the-counter drugs and herbal and "alternative" therapies are more widely used in Europe than in the US, though their popularity in the US is increasing. To the extent that these market characteristics (which are not controlled for in the empirical analysis) are systematically related to the use of price controls, the interpretation of the effect of price controls should be made with caution.

\section{Launch decisions and pharmaceutical regulation}

Many prior studies on the pharmaceutical industry identify factors that should be important in the decision to launch a new drug. Competition in pharmaceuticals exists both within a chemical (branded versus generic, prescription versus over-the-counter) and between different chemicals that treat the same condition. The generic segment garners significant market share within a few years of patent expiration when entry occurs, but not all therapeutic classes (and very few countries) attract such entry. ${ }^{5}$ While many have shown that generic competition has indisputable significance (at least in the US), there is substantial justification for focusing on competition between drugs. Lichtenberg and Philipson (2002) estimate the loss in sales from entry by new drugs for the same therapeutic classification and find that entry by such drugs reduces the PDV of a drug by considerably more than generics. These results are broadly consistent with other studies that emphasize the importance of intermolecular competition, such as Stern (1996) and Berndt et al. (1997). 
In addition to competition, the regulatory environment has a significant bearing on prevailing prices (Danzon and Chao (2000a, 2000b)). Countries with stringent regulation of entry combined with relatively little price regulation, such as the US and the UK, have highly concentrated domestic industries whose products are launched in more foreign markets (Thomas (1994)). One study that addresses international entry (Parker (1984)) shows regulation is related to large differences across countries in the number and mix of products introduced before 1978 . More recent work by Danzon et al. (2003) finds that between 1994 and 1998, drugs introduced in the UK and US markets were launched more slowly into countries with low prices, which often have price regulation. Thus, there is much reason to expect regulation to influence entry.

An important consequence of price controls that relate the domestic price to the prices in foreign markets is that pharmaceutical firms now have incentive to launch their products first in countries where they have the freedom to set a higher price, since this will influence the price in markets with price controls. Price controls may have an additional effect in Europe through parallel imports, permitted between the $15 \mathrm{EU}$ member states since 1995, which enable wholesalers to arbitrage price differences between EU countries. Launching a drug in a country with stringent price controls may depress global revenues if wholesalers in countries with higher prices purchase drugs in price-controlled markets (with lower prices) for domestic resale. Essentially, parallel trade restricts the ability of firms to price discriminate across countries. One possible outcome is that firms serve only the higher price markets: we would observe fewer launches in low price markets as a result of parallel trade.

Regulation also affects drugs and firms differentially within a country, particularly in the costs of gaining regulatory approval (Dranove and Meltzer (1994), Carpenter (2002)). Product characteristics, like therapeutic novelty or indication, and firm characteristics, such as experience with the FDA and domestic status, are related to the speed at which a new drug receives regulatory approval in the US. Data from three other large pharmaceutical markets (the UK, France, and Germany) displays a similar pattern in time-to-market of important drugs, and reveals 
a strong home country advantage: the drugs of domestic firms are approved earlier than those of foreign firms. Beyond the non-uniform effects of regulation, Scott Morton (1999) finds evidence of important firm-specific differences in the entry decisions of generic drug firms. Firm-specific costs are therefore likely to be important in drug launches.

This paper examines another possible source of firm differences. The share of total pharmaceutical R\&D done in the European Union declined from $49 \%$ to 37\% between 1990 and 2000, and European firms increasingly performed their R\&D in the US. ${ }^{6}$ An oft-cited reason for these changes is the use of price controls in most European countries. ${ }^{7}$ It is not obvious why the regulatory environment in a firm's home country would matter since if drug markets are global, all firms face the same incentives regardless of location. However, regulations could affect the strategies of domestic firms (differently from foreign firms) in two ways.

The first mechanism relates to the cost of winning regulatory approval. The domestic market is generally the easiest market to enter (see Kyle (2005), Danzon et al. (2004), Dranove and Meltzer (1994)). For firms whose domestic markets use price controls, this means the price in their initial launch market is probably rather low, and the launch price in subsequent markets will also be low because of parallel trade and international reference pricing. These firms also face higher entry costs into foreign markets, so it is less likely that they would expect variable profits to cover the fixed costs of launch in these additional countries. Firms headquartered in free-pricing countries that introduce a drug in a price-controlled country are also less likely to launch in additional markets after that, but their initial launch is more likely to be in a country with relatively high prices. This implies that firms headquartered in a price-controlled market will tend to introduce their products in fewer foreign markets.

The second mechanism relates to the possibility that price controls are not applied to all firms in the same way. Governments could use price controls to favor domestic producers, perhaps by ignoring therapeutic value in setting price or simply by compensating domestic firms more than foreign firms, so that domestic firms in price controlled countries find it more 
profitable to produce drugs only for their home markets than to develop drugs for use in many countries, and foreign firms do not find it as attractive to follow this strategy. The outcome of this industrial policy is low quality drugs (or of little therapeutic innovation) from domestic firms. Firms located in countries without this industrial policy have incentives to produce high quality drugs (assuming that the market rewards quality with a high price), and these high quality drugs are more likely to succeed in other markets. This mechanism would also generate the prediction of different launch patterns for firms depending on their headquarters location.

\section{Model}

The approach taken in this paper assumes that potential entrants for a market take existing market structure as given and compete simultaneously in time t. Let $\mathrm{i}$ index drugs, $\mathrm{j}$ index firms, $\mathrm{k}$ index therapeutic classes, and 1 index countries. A market is thus a class-countryyear triple. Define the reduced-form profit function as

$$
\Pi_{\mathrm{ijklt}}=\mathrm{N}_{\mathrm{klt}} \delta+\mathrm{M}_{\mathrm{klt}} \theta+\mathrm{X}_{\mathrm{klt}} \beta+\mathrm{Z}_{\mathrm{jklt}} \gamma+\mathrm{W}_{\mathrm{ikt}} \alpha+\varepsilon_{\mathrm{ijklt}}
$$

where $\mathrm{N}$ is the number of competing drugs in the market, $\mathrm{M}$ is the number of potential entrants, $\mathrm{X}$ is a vector of market characteristics, $\mathrm{Z}$ is a vector of firm characteristics, and $\mathrm{W}$ is a vector of drug characteristics. ${ }^{8}$ Firms enter if their expected profits are at least zero, and any firm that elects not to enter must expect negative profits from entry. Included in $\mathrm{W}$ are the characteristics of markets the drug has already been launched in, since entry into a price-controlled market may affect subsequent launch strategies.

This paper takes two estimation approaches to examine the effect of price regulation on the launch decision. One is to estimate whether the number of countries a drug is launched in depends on whether it originates in a price-controlled country. A second approach is to estimate whether price controls delay a drug's launch in a country using a hazard model. These are described in greater detail below.

A. Negative binomial model 
The number of countries in which a drug is launched may be estimated as a Poisson or negative binomial process such that

$$
\operatorname{Prob}\left(\mathrm{C}_{\mathrm{i}}=\mathrm{c}_{\mathrm{i}}\right)=\frac{\mathrm{e}^{-\mu_{\mathrm{i}}} \mu_{\mathrm{i}}^{\mathrm{c}_{\mathrm{i}}}}{\mathrm{c}_{\mathrm{i}} !}
$$

where $\mathrm{c}$ is the count of markets launched in drawn from a negative binomial distribution with parameter $\mu$, and

$$
\log \mu_{\mathrm{i}}=\mathrm{N}_{\mathrm{klt}} \delta+\mathrm{M}_{\mathrm{klt}} \theta+\mathrm{Z}_{\mathrm{jklt}} \gamma+\mathrm{W}_{\mathrm{ikt}} \alpha+\varepsilon_{\mathrm{i}}
$$

with $\varepsilon$ reflecting cross-sectional heterogeneity or specification error. This estimation approach is useful for examining the total number of markets reached during a drug's lifetime as a function of its characteristics and its origins (for example, whether its inventor is located in a market with price controls).

By simply estimating the count of countries entered, each country is essentially assigned equal weight. Since countries vary considerably in size, treating each country equally implies a greater weight per capita given to residents of small countries. The US market is approximately twice the size of the largest five European markets combined, but with the negative binomial estimation approach, a drug launched in those five countries is measured as having reached further. An alternative measure of market reach is the total population with access to a new drug. Therefore, the following equation is estimated using ordinary least squares:

$$
\log (\text { total population })=\mathrm{N}_{\mathrm{klt}} \delta+\mathrm{M}_{\mathrm{klt}} \theta+\mathrm{Z}_{\mathrm{jklt}} \gamma+\mathrm{W}_{\mathrm{ikt}} \alpha+\varepsilon_{\mathrm{i}}
$$

B. Discrete-time hazard

The probability that a drug is launched during a time interval $t$ can be written as

$$
\mathrm{P}(\mathrm{t})=\mathrm{a}(\mathrm{t})+\mathrm{N}_{\mathrm{klt}} \delta+\mathrm{M}_{\mathrm{klt}} \theta+\mathrm{X}_{\mathrm{klt}} \beta+\mathrm{Z}_{\mathrm{jklt}} \gamma+\mathrm{W}_{\mathrm{ikt}} \alpha
$$

where $\mathrm{a}(\mathrm{t})$ is a series of intercepts for each year of a drug's age (or time at risk). A convenient transformation for estimation is the logit, i.e.

$$
\log \left(\frac{\mathrm{P}(\mathrm{t})}{1-\mathrm{P}(\mathrm{t})}\right)=\mathrm{a}(\mathrm{t})+\mathrm{N}_{\mathrm{klt}} \delta+\mathrm{M}_{\mathrm{klt}} \theta+\mathrm{X}_{\mathrm{klt}} \beta+\mathrm{Z}_{\mathrm{jklt}} \gamma+\mathrm{W}_{\mathrm{ikt}} \alpha
$$


This method three convenient features. It accounts for right-censored observations, it does not require a functional form assumption about time-dependence, and it permits the use of time-varying covariates. While the negative binomial estimation described above speaks to the extent of a drug's international launch, the discrete time hazard captures both the speed of launch and the effect of the characteristics of potential markets on the launch decision.

Since drug launches are observed at annual intervals in this dataset, a discrete-time model is probably more appropriate than a continuous time model such as the Cox Partial Maximum Likelihood Estimator, or proportional hazards model. As the interval of observation becomes small, the results from a discrete-time logit converge to those from a proportional hazard model. ${ }^{9}$ While only the estimates from the discrete time model are reported in this paper, results from continuous time models are quite similar.

However, this approach (as well as the use of continuous time hazard models) requires several strong assumptions. Most importantly, the number of potential entrants is treated as an exogenous variable, and there is assumed to be no strategic interaction among firms such as predatory pricing, collusion, or preemptive entry. The latter assumption is difficult to justify, but made to simplify the empirical analysis. As recent papers by Acemoglu and Linn (2003) and Finkelstein (2003) have shown, the number of drugs developed to treat a condition is almost certainly a function of the global profits associated with that disease. However, this paper examines the entry decision into a market conditional on most development costs being sunk, rather than the decision to initiate the development of a drug. Since the average time to bring a drug to market is on the order of 7-8 years, the number of potential entrants is effectively fixed when the firm decides whether to launch a drug in an additional country. 
V. Data

Information on all drugs developed between 1980 and 2000 is obtained from the Pharmaprojects database, which is maintained by the UK consulting firm PJB Publications. This dataset includes the drug's chemical and brand names, the name and nationality of the firm that developed it, the identity of licensees, the country and year in which it was patented, its status (in clinical trials, registered, or launched) in the 28 largest pharmaceutical markets, and the year of launch where applicable. Each drug is assigned to up to six therapeutic classes. The system of classification used by Pharmaprojects is adapted from the European Pharmaceutical Market Research Association; there are 17 broad disease areas (for example, dermatological conditions) and 199 more specific classes (such as antipsoriasis treatments). The sample of drugs used in this research is restricted to those that are new chemical or molecular entities by dropping new formulations of existing products, OTC licensing opportunities, antidotes, and diagnostic agents for a total of 147 classes used in the analysis.

The OECD Health Data 2000 dataset provides population, GDP, data on access to health care, and other demographic information for OECD countries. Of the 28 countries in Pharmaprojects, 21 are also OECD members. The regulatory structure of each country is classified as "price control regime" using the summary tables from Jacobzone's "Pharmaceutical Policies in OECD Countries: Reconciling Social and Industrial Goals." Additional detail for major European markets was collected from "The Guide to European Pharmaceutical Pricing and Reimbursement Systems." Table 2 presents information on the various regulations in use across countries.

A market is defined as a country-therapeutic class-year triple. This definition assumes that drugs with the same therapeutic classification are substitutes, and that there is no substitution between therapeutic classes. Of course, the latter assumption is a strong one. Different classes of products may be appropriate for the same condition. A patient with migraine headaches might be 
prescribed a treatment specifically for migraines, an NSAID, or a narcotic; these represent three distinct classes. Other therapeutic classes may be complements - drugs that have nausea as a side effect are often prescribed in conjunction with an anti-nausea treatment, for instance. In addition, this market definition requires that there be no trade in unapproved products across international borders: launching a drug in the US must not enable access to the Canadian market. While the move to a common market in Europe weakens the assumption of separate markets, negotiation with health ministries is still necessary for the drug to be reimbursed. This is an important point: it means competition from drugs approved in nearby countries but without local insurance coverage is probably weak. Entry, or launch, is defined as the date a firm has completed all negotiations with government agencies. This includes not only receiving approval, but also setting ex-manufacturer or reimbursement prices in countries that regulate them. A drug is "at risk" for entry into all markets beginning in the year of its first launch into any country. After launch in a market, it drops out of the risk set for that country. Any drug that has been approved somewhere in the world for a particular therapeutic class is a potential entrant into that therapeutic class in all other countries.

Drug quality, or the therapeutic advance a treatment represents, is likely an important factor in both the fixed costs of entry (if regulators accelerate approval of breakthrough therapies, or if regulatory approval is more difficult to obtain for a novel type of therapy with which regulators are unfamiliar) and in variable profits. Unfortunately, objective measures of quality are difficult to obtain. Previous studies have used the ratings of therapeutic novelty assigned by the FDA upon application for approval, but these are unavailable for drugs that did not seek entry into the US. Pharmaprojects also ranks drugs according to their novelty, but this ranking is retrospective, so a drug that represented a therapeutic advance at its initial launch ten years ago may be rated an established therapy in the current database. The "Essential Drug List" of the World Health Organization is another possibility, but it is updated infrequently and most of the drugs on the list are more than twenty years old. Therefore, this research follows Dranove and 
Meltzer (1994) in using mentions of a drug in medical journals indexed by Medline. The assumption is that important drugs are mentioned in journals because they are the "gold standard" of clinical care, or promising in many clinical studies. ${ }^{10}$ The measure used in this work is a drug's share of total mentions of all drugs in its therapeutic class. Other aspects of drug quality are the number and severity of adverse interactions and side effects, dosage form, and dosage frequency. Systematic data on these characteristics is unavailable, particularly for drugs not marketed in the US.

Quantifying the regulatory barrier to entry, as well as the severity of price regulation, is nearly impossible. One indication is the time between application and approval of a drug. However, not only is this unavailable in all markets, but is also likely to be a function of drug quality, firm characteristics, the number of other drugs under review, and perhaps the decisions of regulators in other countries, and is therefore an imperfect measure. The variety of regulations in these nations is difficult to categorize neatly, and it is also difficult to separately identify the effects of each regulatory mechanism. The existence of price regulation in a country is captured by a set of dummy variables, which obscures differences in the implementation of such policies, as described in Section II. All regulatory variables are vulnerable to endogeneity problems, as such policies may be reactions to (the perception of) high profits earned by pharmaceutical companies. Only four countries (Canada, Mexico, the Netherlands, and Sweden) enacted price controls during the sample period. Other omitted variables include the importance of generic competition within a country (or therapeutic class), the degree to which marketing of pharmaceuticals is regulated, the cost of marketing in each country, heterogeneity in prescribing behavior, and other subtle but important distinctions between countries.

Table 3 presents summary statistics for data used in estimation. The sample used in estimation contains 1444 unique molecules produced by 278 firms in 134 therapeutic classifications, for a total of 51,525 country-class-year markets. There were 299,567 entry opportunities, only 7,630 of which had a product launch. The mean number of drugs competing 
in markets with entry opportunities is 2.6. The distribution of the number of competitors over all markets is shown in Figure 1, both for the entire time period and as of 2000. Most markets are highly concentrated, and over one-fourth have no entry at all. The large fraction of " 0 " markets reflects both that some drugs are never launched in a country and that some drugs are only introduced years after they first become available elsewhere. However, even as of $2000,15 \%$ of markets are empty.

Country-level demographics provide rough measures of market size and demand. Ideally, incidence rates at the level of country-class would be included, but these are difficult to obtain and may also be endogenous if pharmaceuticals reduce the occurrence of disease. In general, additional country-level variables such as the number of doctors per capita, pharmaceutical spending, and life expectancy proved insignificant ${ }^{11}$ and so only a parsimonious set of variables is presented here. To control for other country-specific factors that may be correlated with the use of price controls and that might also affect entry decisions, the 1995 Transparency International Corruption Index ${ }^{12}$ and two measures from Djankov et al. are included: an index of market competition and an estimate of the cost of registering a new business as a percent of GDP per capita. Including these country-specific (rather than country-industry specific) measures enables isolating the effect of pharmaceutical price controls from general bureaucratic problems associated with a country. In addition, a measure of each country's relative price ranking is included (as published in "The Guide to European Pharmaceutical Pricing and Reimbursement Systems" using data from regulators in France and Germany), although price comparisons across countries are difficult due to different sets of products available and exchange rate fluctuations. The inclusion of this variable is an attempt to control for the stringency of price controls (how much they bind) and to test whether delayed entry into a market is due entirely to low prices, or partly caused by delays in negotiating price.

Variables measured at the drug-year level include age, the number of countries in which the drug has been introduced, and its share of the stock of Medline citations for its therapeutic 
class. There may be economies of scale in global production, as clinical trial data is accumulated and used in subsequent applications, or if regulators are exposed to less political risk in approving a drug that has already been accepted by their counterparts in other countries. The probability of entry is thus expected to be concave in the number of launch countries. A drug's value should decline with age, due to the limited period of patent protection and competition from newer therapies, so entry is predicted to be convex in age. Drugs that are the subject of many scientific studies should be more profitable, so a positive coefficient on the measure of drug importance is expected.

Several firm-level variables are included. International experience is the count of the number of countries in which the firm markets any drug. A firm's experience in a country is defined as the count of drugs it markets in that country. These capture economies of scale and scope: experience with the regulator and the presence of a detailing force may be spread across all a firm's products within a country, and there may be economies of scale in global distribution. Care should be taken in interpreting the coefficients on these variables, though, since they may only be picking up duration dependence, or the effect of an unobserved factor for all a firm's launches in a market over time.

VI. Results

\section{A. Extent of international launch}

Table 4 provides estimation results from the negative binomial models ${ }^{13}$ and OLS models of the number of countries launched in and the log of total population reached, respectively, eight years after a drug's initial launch. Similar results obtain after four and twelve years, but eight is roughly the number of years of market exclusivity for most drugs. All specifications include year and therapeutic class fixed effects. There are no noteworthy differences in the results from the negative binomial and linear specifications. 
In general, the coefficients are consistent with expectations. Important drugs enter more countries, and pharmaceuticals invented by firms that are active in many countries are likely to reach more markets. However, firms with many drugs in their portfolios tend to launch their drugs in fewer countries. This suggests some effort on the part of multiproduct firms to match a market to the most appropriate treatments, or perhaps a portfolio of "me-too" products - those that are chemically similar to existing drugs and that offer little therapeutic advance - that are unlikely to succeed in many markets.

The results suggest that drugs invented by firms in countries with price controls tend to be less successful on the global market. In Models 1 and 3, the coefficient on the dummy variable indicating whether the firm's domestic market regulates price is negative and significant at the $1 \%$ level, implying that drugs invented by firms in price-controlled countries reach 2 fewer markets on average. One interpretation of this pattern is that the incentives created by price control regimes spur firms in these countries to introduce new products that are slightly different from, but not a huge advance over, their existing products, because the prices of their existing products are ratcheted down by regulators over time. Thomas (2001) believes this is particularly true for Japanese firms, and more recently, Duggan and Scott Morton (2004) find evidence that Medicaid reimbursement laws have prompted a similar strategy in the US. However, all pharmaceutical firms should face these incentives unless entry regulation or price controls have different effects on firms from different countries. That is, a British firm should be able to reap the same rewards from introducing a "me-too" product on the Italian market as an Italian firm, unless the British firm faces higher entry costs or expects a lower price (and lower profits) than the Italian firm in Italy. In addition, the measure of quality used should control for "me-too" drugs that generate few medical citations (although there are many shortcomings associated with this control). An alternative interpretation is that countries with price controls happen to have populations with idiosyncratic needs, and domestic firms are better suited to developing drugs for those needs. Absent a reason why only countries with price controls would have such 
idiosyncratic needs, however, this interpretation seems incomplete. Thus, there is some evidence that price controls or entry regulations may be used by governments as a tool of industrial policy to favor domestic firms.

The other explanation offered in Section III was that if domestic firms face lower entry costs into their own markets, the initial market of firms headquartered in price-controlled countries is likely to be a relatively low price one. Due to international reference pricing and parallel trade, an early launch in a low price country can make subsequent launches less attractive. Models 2 and 4 include dummy variables indicating whether a drug was first launched in a domestic or foreign market, and whether the first market was price-controlled. (The results are similar if "low price" and "high price" markets are defined instead of price-controlled or freepricing.) Relative to the omitted category, which includes drugs launched first in domestic markets without price controls, products whose first country of introduction is price-controlled (either domestic or foreign) are launched in 1.7-1.9 fewer markets after 8 years. The results from these specifications are consistent with the explanation that if the first launch is in a pricecontrolled country, and most first launches are in the domestic market, then the country of headquarters can affect the launch patterns of new drugs. These results also suggest that price controls affect entry decisions not only in the country that impose them, but also other potential markets.

B. Launch order and timing strategies

Results from the discrete time hazard models are presented in Table 5, along with the marginal effects at the mean of the independent variables. All models include year and therapeutic class fixed effects, though the individual coefficients are not reported. Country fixed effects are not included since the variables of greatest interest, those measuring the use of price controls, have little intracountry variation. Model 1 is the most parsimonious specification; Model 2 includes more detailed measures of cost-containment regulations for the subset of countries for which such data exist; and Model 3 adds interactions between the price rank of a 
potential launch market with a dummy variable for the post-1995 period (when parallel trade within the EU became significantly easier).

Results for most variables are fairly stable across all specifications, and the marginal effects are often quantitatively important given that the mean probability of entry is only $3 \%$. As would be expected, countries with large populations are likely to be launched in quickly, although the coefficient on GDP per capita is negative and statistically insignificant in Models 2 and 3. The existence of competing drugs in a market is associated with increased rates of entry as well, which is likely due to the correlation of previous entry with unobserved demand in that country. ${ }^{14}$ Domestic firms tend to enter the market with short delays (entry into a domestic market is four times greater than into a foreign market), as do firms with extensive international experience or that have greater experience in the market. The speed of launch increases with a drug's importance and the number of other markets it has entered, but falls with age, as the patent nears expiration and more innovative products may have been developed (coefficients are not reported to conserve space, but are available from the author). Consistent with the results from the models for extent of launch, drugs invented by firms headquartered in price-controlled countries are less likely to be introduced in additional markets. Entry is less likely in markets with high entry costs for other industries. The coefficients on the measures of corruption and market competition indicate that countries with less market competition and higher perceptions of corruption are actually more attractive for entry.

The effect of price controls is quite substantial, even after controlling for the average level of prices in a country and other country-level factors. The coefficients on the main effect of the price control or supply-side control dummies range from -.324 to -.452 , depending on the specification, and these estimates are all statistically significant at the $1 \%$ level. At the mean of all other variables, this implies about a $75 \%$ reduction in the probability of entry relative to a country without price controls. Interestingly, the use of demand-side controls does not appear to have a negative effect on launch. It may be that some of these controls are not enforced 
particularly well (for example, in most countries the penalty for exceeding the prescribing budget amounts to a stern letter to the errant doctor). Entry actually appears more likely in countries using therapeutic class reference pricing. There is some evidence, therefore, that demand-side controls may be preferable to explicit price controls from the standpoint of attracting new drugs.

The coefficient on the price rank of a country is negative and significant in Models 2 and 3 , which is somewhat surprising. It implies that high price markets are less attractive for launch. However, it is certainly possible that there are entry barriers which are not captured by any of the country-level control variables and which are higher for high price markets. Importantly, a drug that has been previously launched in a high price market is much more likely to enter an additional market than those previously launched in low price markets. (The excluded category includes countries for which no price ranking exists, which tend to be Asian or South American countries.) When an interaction term with the post-1995 period is included (Model 3), it appears that launch in higher price countries is more likely when parallel trade is more widespread. Since parallel traders can essentially arbitrage price differences across countries in the EU, entry into high price countries should be more attractive, and entry into low price markets less so, as imports of drugs from low price countries could crowd out sales in higher price markets.

These patterns are consistent with firms' preference for entry into markets with free pricing first, reaping profits from high prices for as long as possible, and launching their products in low price markets as late as possible given the constraints of a limited period of patent protection and the threat of entry by competitors in these markets. It suggests that the effect of price controls is not isolated to an individual market, but rather affects the launch of a drug in other markets as well.

\section{Conclusion}

While firm and product characteristics have substantial effects on the entry pattern of a new drug, this research demonstrates that the impact of price regulations used in many developed 
countries also has a large bearing on launch patterns. Price controls delay or reduce the probability of launch in countries that impose them, and these effects carry over into other markets as well. Price controls appear to have differential impacts on foreign and domestic firms, and negatively affect the extent of international launch for products invented by domestic firms.

There are two implications for public policy from this research. The costs of deterring innovative products that may result from imposing price controls should be balanced against any short-run savings from lower prices, in addition to concerns about the long-run effects on $R \& D$ incentives and the development of future products. Second, the effect of price controls is not isolated to a single market, but influences the global launch decisions of pharmaceutical firms and thus impacts the extent and timing of a new drug's launch. These results have particular salience as individual states in the US adopt price control measures to control Medicaid costs, and as the federal government considers similar legislation. The strategic response to changes in links between markets, such as international reference pricing and parallel trade, should also be considered for poorer countries expected to enter the EU and for developing countries elsewhere. One effect of efforts to keep prices low in such countries could be a reduction in the number of innovative products available.

However, some important caveats warrant mention. Price controls may be an endogenous response to some other factor not captured in the regressions presented here. They may also be correlated with an omitted variable, such as other industrial policies or drug safety regulation. In addition, this research makes no statements about the effect of price controls on total social welfare. It may well be that the increased use of pharmaceuticals that results from lower drug prices more than outweighs the costs associated with delays to market or reduction in incentives for R\&D. Estimation of welfare would require considerably more detailed information on prices and consumption. Future work should also incorporate better measures of countryspecific demand and costs associated with product launch. Lastly, a structural approach that 
addresses the problem of endogenous entry by competitors and responses by governments and that examines the nature of competition in these markets may be appropriate.

\section{References}

Acemoglu, D. and J. Linn (2004), "Market Size in Innovation: Theory and Evidence from the Pharmaceutical Industry," Quarterly Journal of Economics, forthcoming.

Allison, P. (1984), Event History Analysis: Regression for Longitudinal Event Data, Newbury Park, CA: Sage Publications.

Amemiya, T. (1985), Advanced Econometrics, Cambridge, MA: Harvard University Press.

Berndt, E. L. Bui, D. Lucking-Reily and G. Urban (1997), “The Roles of Marketing, Product Quality and Price Competition in the Growth and Composition of the US Anti-Ulcer Drug Industry," chapter 7 in Timothy F. Bresnahan and Robert J. Gordon, eds., The Economics of New Goods, Studies in Income and Wealth, Volume 58, Chicago: University of Chicago Press for the National Bureau of Economic Research, 277-322.

Carpenter, D. (2002), "Groups, the Media, and Agency Waiting Costs: the Political Economy of FDA Drug Approval,” American Journal of Political Science 46(3), 490-505.

Caves, R., M. Whinston and M. Hurwitz (1991), "Patent Expiration, Entry, and Competition in the US Pharmaceutical Industry," Brookings Papers on Economic Activity: Microeconomics, 1-48.

Danzon, P. and L. Chao (2000), “Cross-National Price Differences for Pharmaceuticals: How Large, and Why?” Journal of Health Economics, 19, 159-195.

Danzon, P. and L. Chao (2000), "Does Regulation Drive Out Competition in Pharmaceutical Markets?" Journal of Law and Economics, 43, 311-357.

Danzon, P., Y. R. Wang and L. Wang (2005), “The Impact of Price Regulation on the Launch Delay of New Drugs - Evidence from 25 Major Markets in the 1990s," Health Economics, 14, 269-292. 
Djankov, S., R. La Porta, F. Lopez-de-Silanes, and A. Shleifer (2002), “The Regulation of Entry,” Quarterly Journal of Economics 117(1): 1-38.

Dombey, D. and V. Griffith (2002), “Seeking Freedom in New England: The decision by Novartis to move research to Boston is the latest step away from Europe by a big pharmaceutical firm," Financial Times, May 8, 2002, p. 21.

Duggan, M. and F. Scott Morton (2004), “The Distortionary Effects of Government Procurement: Evidence from Medicaid Prescription Drug Purchasing,” NBER Working Paper 10930.

Dranove, D. and D. Meltzer (1994), “Do Important Drugs Reach the Market Sooner?” RAND Journal of Economics 25(3), 402-423.

Ellison, S., I. Cockburn, Z. Griliches and J. Hausman, "Characteristics of Demand for Pharmaceutical Products: An Examination of Four Cephalosporins," RAND Journal of Economics, 28(3), 426-46.

Finkelstein, A. (2004), "Static and Dynamic Effects of Health Policy: Evidence from the Vaccine Industry," Quarterly Journal of Economics, 119(2), 527-564.

Grabowski, H. G., J. Vernon and L.G. Thomas (1978), "Estimating the Effects of Regulation on Innovation: An International Comparative Analysis of the Pharmaceutical Industry," Journal of Law and Economics, 21(1), 133-163.

Grabowski, H. and J. Vernon (1992), "Brand Loyalty, Entry and Price Competition in Pharmaceuticals After the 1984 Drug Act," Journal of Law and Economics 35, 331-350.

Hudson, J. (2000), “Generic Take-up in the Pharmaceutical Market Following Patent Expiry: a Multi-country Study," International Review of Law and Economics 20, 205-221.

Jacobzone, S. (2000), "Pharmaceutical Policies in OECD Countries: Reconciling Social and Industrial Goals,” OECD Labour Market and Social Policy Occasional Paper \#40.

Lichtenberg, F. and Philipson, T. (2002), “The Dual Effects of Intellectual Property Regulations: Within- and Between-Competition in the US Pharmaceuticals Industry," Journal of Law and Economics, 45, 643-672. 
Kyle, M. (2005), “The Role of Firm Characteristics in Pharmaceutical Product Launches,” Duke University mimeo.

Parker, J. (1984), The International Diffusion of Pharmaceuticals, London: Macmillan Press.

Scott Morton, F. (1999), "Entry Decisions in the Generic Pharmaceutical Industry," RAND Journal of Economics, 30(3), 1-22.

Stern, S. (1996), "Market Definition and the Returns to Innovation: Substitution Patterns in Pharmaceutical Markets," MIT POPI Working Paper.

Thomas, L.G. (1994), "Implicit Industrial Policy: The Triumph of Britain and the Failure of France in Global Pharmaceuticals," Industrial and Corporate Change, 2(3), 451-489.

Thomas, L.G. (2001), The Japanese Pharmaceutical Industry, Cheltenham, UK: Es\dward Elgar Publishing. 
Table 1: Origin and launch markets

\begin{tabular}{|c|c|c|c|c|c|c|c|c|c|c|c|c|}
\hline Launch & 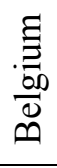 & 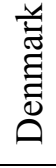 & 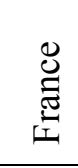 & 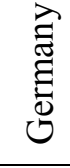 & $\vec{\lambda}$ & 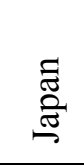 & 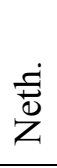 & 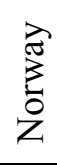 & 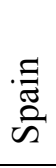 & 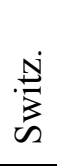 & 光 & 岕 \\
\hline Argentina & 2 & 3 & 62 & 39 & 27 & 38 & 11 & 2 & 7 & 35 & 27 & 115 \\
\hline Australia & 1 & 8 & 41 & 25 & 3 & 34 & 10 & 2 & & 43 & 60 & 159 \\
\hline Austria & 2 & 10 & 29 & 50 & 12 & 36 & 10 & 5 & & 33 & 27 & 106 \\
\hline Belgium & 3 & 13 & 65 & 50 & 14 & 34 & 11 & 4 & 2 & 46 & 55 & 171 \\
\hline Brazil & 2 & 4 & 47 & 31 & 25 & 24 & 9 & & 4 & 24 & 22 & 102 \\
\hline Canada & 1 & 8 & 44 & 17 & 7 & 31 & 8 & 4 & & 42 & 51 & 162 \\
\hline Colombia & 1 & 2 & 28 & 21 & 12 & 19 & 5 & & 4 & 22 & 20 & 62 \\
\hline Denmark & 1 & 16 & 40 & 28 & 5 & 35 & 12 & 4 & 2 & 39 & 51 & 154 \\
\hline France & 2 & 10 & 133 & 56 & 18 & 57 & 18 & 4 & 1 & 63 & 57 & 216 \\
\hline Germany & 4 & 14 & 97 & 108 & 18 & 70 & 16 & 7 & 2 & 75 & 76 & 259 \\
\hline Greece & 2 & 11 & 51 & 22 & 17 & 23 & 10 & 3 & 2 & 31 & 23 & 109 \\
\hline Ireland & 1 & 14 & 36 & 23 & 8 & 28 & 9 & 3 & & 34 & 52 & 127 \\
\hline Italy & 3 & 8 & 92 & 67 & 96 & 66 & 14 & 5 & 3 & 53 & 75 & 185 \\
\hline Japan & 5 & 6 & 46 & 52 & 9 & 298 & 14 & 2 & 3 & 44 & 34 & 151 \\
\hline Mexico & 2 & 2 & 38 & 29 & 15 & 38 & 9 & 1 & 7 & 26 & 28 & 99 \\
\hline Netherlands & 2 & 11 & 45 & 33 & 8 & 31 & 13 & 3 & 3 & 29 & 45 & 133 \\
\hline Peru & 1 & & 30 & 18 & 5 & 20 & 5 & 1 & 6 & 18 & 15 & 49 \\
\hline Philippines & 2 & 3 & 35 & 28 & 13 & 38 & 6 & 1 & 1 & 25 & 29 & 94 \\
\hline Portugal & 2 & 6 & 58 & 37 & 26 & 34 & 8 & 3 & 7 & 29 & 37 & 113 \\
\hline South Africa & 2 & 7 & 33 & 26 & 8 & 28 & 8 & 2 & & 25 & 43 & 128 \\
\hline South Korea & 3 & 5 & 50 & 40 & 31 & 104 & 10 & 1 & 8 & 19 & 19 & 83 \\
\hline Spain & 2 & 12 & 79 & 59 & 35 & 57 & 11 & 3 & 36 & 56 & 66 & 182 \\
\hline Sweden & 1 & 14 & 31 & 23 & 3 & 29 & 11 & 3 & 2 & 37 & 50 & 147 \\
\hline Switzerland & 3 & 13 & 64 & 57 & 16 & 37 & 13 & 2 & 2 & 77 & 47 & 183 \\
\hline Turkey & 1 & 1 & 19 & 5 & 9 & 9 & 9 & 1 & & 20 & 18 & 29 \\
\hline UK & 3 & 16 & 73 & 45 & 10 & 45 & 15 & 3 & 1 & 62 & 97 & 237 \\
\hline USA & 2 & 9 & 56 & 38 & 7 & 55 & 15 & 4 & & 51 & 70 & 307 \\
\hline Venezuela & 2 & 1 & 19 & 11 & 11 & 16 & 6 & & 3 & 12 & 15 & 50 \\
\hline
\end{tabular}

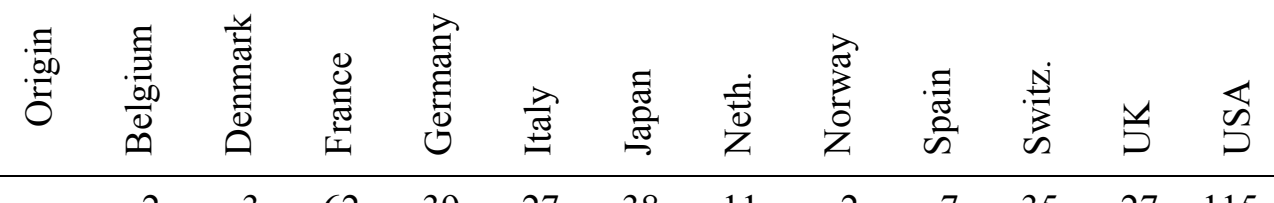

Numbers in cells represent introductions of drugs invented by firms headquartered in the "origin" country (columns) in the "launch country" (rows). Origin countries with fewer than 50 total launches are excluded from the table. Note the tendency to launch most drugs in the country of origin. 
Table 2: Regulatory structure of countries

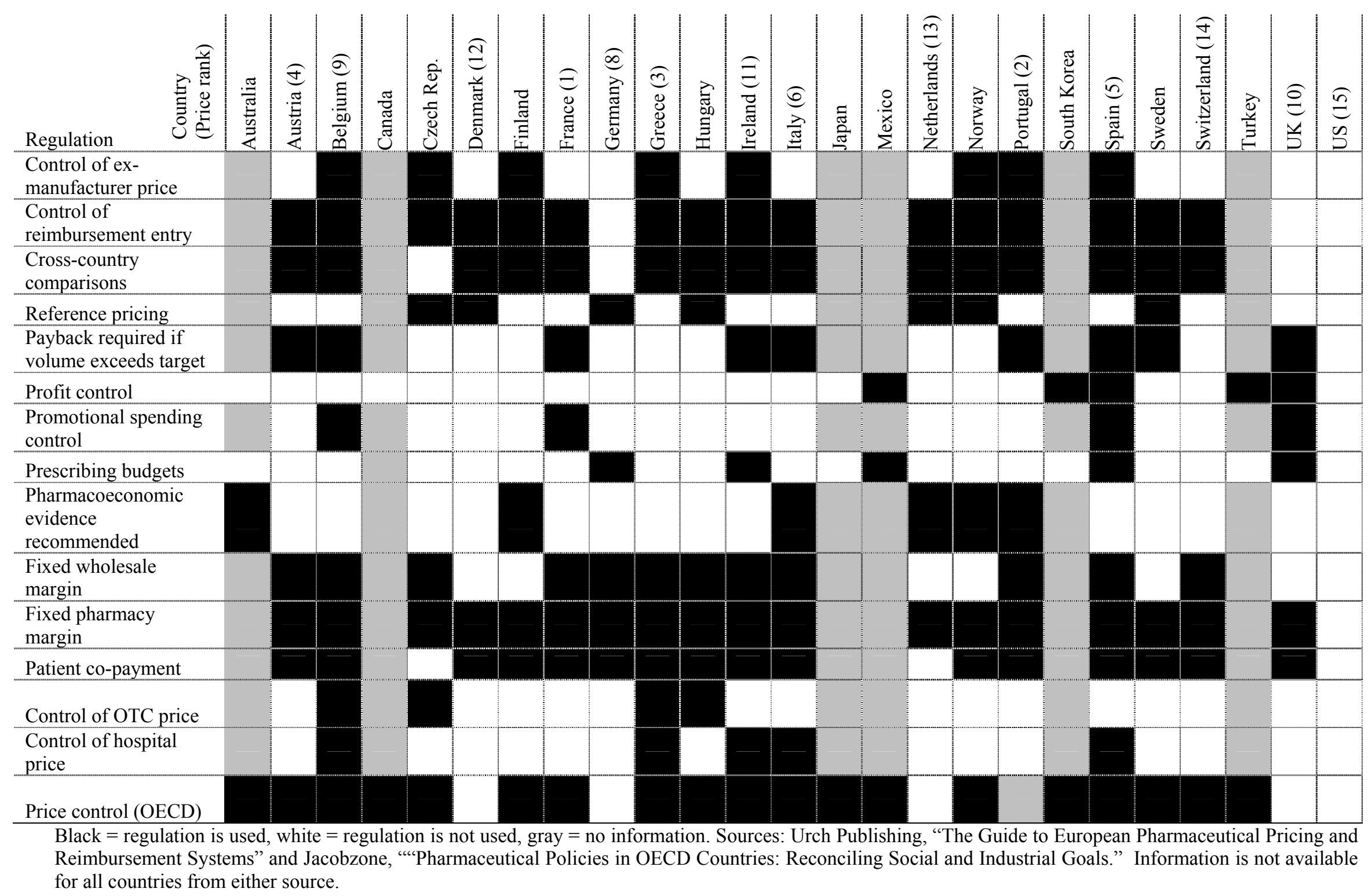


Table 3: Summary Statistics

\begin{tabular}{|c|c|c|c|c|c|c|c|}
\hline \multicolumn{2}{|l|}{ Number of drugs } & 1444 & & & & & \\
\hline \multicolumn{2}{|l|}{ Number of firms } & 278 & & & & & \\
\hline \multicolumn{2}{|c|}{ Number of therapeutic classes } & 134 & & & & & \\
\hline \multicolumn{2}{|l|}{ Years covered } & 1980-1999 & & & & & \\
\hline \multicolumn{2}{|c|}{$\begin{array}{l}\text { Number of markets (country-class-year } \\
\text { observations) }\end{array}$} & 51525 & & & & & \\
\hline \multicolumn{2}{|c|}{$\begin{array}{l}\text { Number of entry opportunities (drug-country- } \\
\text { class-year observations) }\end{array}$} & 299567 & & & & & \\
\hline \multicolumn{2}{|c|}{ Number of entry events } & 7630 & & & & & \\
\hline $\begin{array}{c}\text { Level of } \\
\text { observation }\end{array}$ & Variable & Definition & Obs & Mean & Std Dev & Min & Max \\
\hline $\begin{array}{l}\text { Firm-country- } \\
\text { year }\end{array}$ & Country experience & $\begin{array}{l}\text { Count of firm's other drugs launched in } \\
\text { country }\end{array}$ & 73827 & 3.226 & 6.149 & 0 & 39 \\
\hline \multirow[t]{2}{*}{$\begin{array}{l}\text { Country-class- } \\
\text { year }\end{array}$} & Number of drugs in market & $\begin{array}{l}\text { Count of drugs in therapeutic class-count } \\
\text { market }\end{array}$ & 48833 & 2.624 & 3.358 & 0 & 30 \\
\hline & $\begin{array}{l}\text { Number of potential } \\
\text { competitors }\end{array}$ & $\begin{array}{l}\text { Count of drugs launched in class elsewhe } \\
\text { in the world }\end{array}$ & 48833 & 9.321 & 8.712 & 1 & 79 \\
\hline \multirow[t]{5}{*}{ Drug-year } & Drug age & $\begin{array}{l}\text { Number of years since drug's first } \\
\text { launch anywhere }\end{array}$ & 18733 & 8.257 & 5.129 & 0 & 15 \\
\hline & $\begin{array}{l}\text { Number of countries } \\
\text { launched in }\end{array}$ & & 18733 & 6.049 & 6.646 & 0 & 27 \\
\hline & Drug importance & $\begin{array}{l}\text { Drug's share of stock of Medline citation } \\
\text { for therapeutic class }\end{array}$ & 18733 & 0.010 & 0.066 & 0 & 1 \\
\hline & $\begin{array}{l}\text { Prior launch in a high price } \\
\text { country }\end{array}$ & $\begin{array}{l}\text { Dummy }=1 \text { if drug has been launched in } \\
\text { country with price rank }>7\end{array}$ & 18733 & 0.362 & 0.481 & 0 & 1 \\
\hline & $\begin{array}{l}\text { Prior launch in a low price } \\
\text { country }\end{array}$ & $\begin{array}{l}\text { Dummy }=1 \text { if drug has been launched in } \\
\text { country with price rank }<7\end{array}$ & 18733 & 0.533 & 0.499 & 0 & 1 \\
\hline Firm-country & Home country & $\begin{array}{l}\text { Dummy }=1 \text { if firm is headquartered in } \\
\text { country }\end{array}$ & 5801 & 0.044 & 0.205 & 0 & 1 \\
\hline \multirow[t]{2}{*}{ Firm-year } & International experience & $\begin{array}{l}\text { Count of countries in which firm has } \\
\text { launched any drugs }\end{array}$ & 3813 & 9.243 & 9.284 & 0 & 28 \\
\hline & Portfolio & Total number of firm's drugs & 3813 & 4.949 & 8.762 & 1 & 80 \\
\hline Firm & $\begin{array}{l}\text { Firm is headquartered in a } \\
\text { price-controlled country }\end{array}$ & & 278 & 0.493 & 0.501 & 0 & 1 \\
\hline \multirow[t]{3}{*}{ Country-year } & Population & Population in 10 s of millions & 420 & 4.538 & 5.527 & 0.34 & 27.29 \\
\hline & GDP per capita & GDP per capita in US $\$ 1000 \mathrm{~s}$, PPP & 420 & 14.265 & 6.279 & 2.25 & 31.94 \\
\hline & Price freeze & $\begin{array}{l}\text { Dummy }=1 \text { if country has a price } \\
\text { freeze in effect }\end{array}$ & 420 & 0.181 & 0.385 & 0 & 1 \\
\hline \multirow{3}{*}{$\begin{array}{l}\text { Country } \\
\text { (see Table } 2 \text { for } \\
\text { regulation } \\
\text { measures) }\end{array}$} & Corruption Index & $\begin{array}{l}\text { TI's "Perceived Corruption Index" } \\
\text { (higher score = less corruption) }\end{array}$ & 420 & 6.790 & 2.094 & 2.99 & 9.32 \\
\hline & Market competition index & Measures from Djankov et al. & 420 & 5.252 & 0.377 & 4.4 & 5.9 \\
\hline & $\begin{array}{l}\text { Entry costs as percent of } \\
\text { GDP per capita }\end{array}$ & & 420 & 0.166 & 0.152 & 0 & 0.59 \\
\hline
\end{tabular}


Table 4: Extent of launch

\begin{tabular}{|c|c|c|c|c|c|c|}
\hline \multirow{3}{*}{ Variable } & \multicolumn{4}{|c|}{$\begin{array}{c}\text { Negative Binomial } \\
Y=(N \text { countries entered })\end{array}$} & \multicolumn{2}{|c|}{$\begin{array}{c}\text { Linear } \\
Y=\ln (\text { population reached })\end{array}$} \\
\hline & \multicolumn{2}{|c|}{ Model 1} & \multicolumn{2}{|c|}{ Model 2} & \multirow{2}{*}{$\begin{array}{l}\text { Model } 3 \\
\text { Coef. } \\
\text { (Std Err) }\end{array}$} & \multirow{2}{*}{$\begin{array}{l}\text { Model } 4 \\
\text { Coef. } \\
\text { (Std Err) }\end{array}$} \\
\hline & $\begin{array}{l}\text { Coef. } \\
\text { (Std Err) }\end{array}$ & $\mathrm{dY} / \mathrm{dX}$ & $\begin{array}{l}\text { Coef. } \\
\text { (Std Err) }\end{array}$ & $\mathrm{dY} / \mathrm{dX}$ & & \\
\hline Number of potential entrants & $\begin{array}{c}0.002 \\
(0.007)\end{array}$ & 0.011 & $\begin{array}{c}0.004 \\
(0.006)\end{array}$ & 0.013 & $\begin{array}{c}0.002 \\
(0.008)\end{array}$ & $\begin{array}{c}0.003 \\
(0.008)\end{array}$ \\
\hline International experience & $\begin{array}{l}0.032 * * \\
(0.004)\end{array}$ & 0.256 & $\begin{array}{l}0.037 * * \\
(0.004)\end{array}$ & 0.278 & $\begin{array}{l}0.030 * * \\
(0.005)\end{array}$ & $\begin{array}{l}0.033 * * \\
(0.005)\end{array}$ \\
\hline Portfolio & $\begin{array}{l}-0.005 * * \\
(0.002)\end{array}$ & -0.040 & $\begin{array}{l}-0.005^{* *} \\
(0.002)\end{array}$ & -0.038 & $\begin{array}{l}-0.004 \\
(0.002)\end{array}$ & $\begin{array}{l}-0.004 \\
(0.002)\end{array}$ \\
\hline Drug importance & $\begin{array}{l}0.655^{* *} \\
(0.154)\end{array}$ & 3.262 & $\begin{array}{l}0.730 * * \\
(0.156)\end{array}$ & 3.613 & $\begin{array}{l}0.667 * * \\
(0.252)\end{array}$ & $\begin{array}{l}0.713 * * \\
(0.250)\end{array}$ \\
\hline $\begin{array}{l}\text { Firm is headquartered in a } \\
\text { price-controlled country }\end{array}$ & $\begin{array}{l}-0.349 * * \\
(0.062)\end{array}$ & -2.049 & & & $\begin{array}{l}-0.208 * * \\
(0.075)\end{array}$ & \\
\hline $\begin{array}{l}\text { First launch market is } \\
\text { domestic and price-controlled }\end{array}$ & & & $\begin{array}{l}-0.336^{* *} \\
(0.080)\end{array}$ & -1.706 & & $\begin{array}{l}-0.260 * \\
(0.101)\end{array}$ \\
\hline $\begin{array}{l}\text { First launch market is foreign } \\
\text { and price-controlled }\end{array}$ & & & $\begin{array}{l}-0.398 * * \\
(0.083)\end{array}$ & -1.887 & & $\begin{array}{l}-0.458 * * \\
(0.107)\end{array}$ \\
\hline $\begin{array}{l}\text { First launch market is foreign } \\
\text { and free-pricing }\end{array}$ & & & $\begin{array}{l}-0.022 \\
(0.075)\end{array}$ & 0.182 & & $\begin{array}{l}-0.088 \\
(0.100)\end{array}$ \\
\hline Observations & & & 9 & & 979 & 979 \\
\hline Log Likelihood or Adj. $\mathrm{R}^{2}$ & -26 & & -268 & & 0.2021 & 0.2189 \\
\hline
\end{tabular}

$*=5 \%$ significance, $* *=1 \%$. Marginal effects are computed at the mean of all independent variables; marginal effects for dummy variables represent the change from 0 to 1 . All specifications include year and therapeutic class fixed effects. 
Table 5: Discrete time hazard of launch

\begin{tabular}{|c|c|c|c|c|c|c|}
\hline \multirow[b]{2}{*}{ Variable } & \multicolumn{2}{|c|}{ Model 1} & \multicolumn{2}{|c|}{ Model 2} & \multicolumn{2}{|c|}{ Model 3} \\
\hline & $\begin{array}{c}\text { Coef. } \\
\text { (Std Err) }\end{array}$ & $\mathrm{dY} / \mathrm{dX}$ & $\begin{array}{c}\text { Coef. } \\
\text { (Std Err) }\end{array}$ & $\mathrm{dY} / \mathrm{dX}$ & $\begin{array}{c}\text { Coef. } \\
\text { (Std Err) }\end{array}$ & $\mathrm{dY} / \mathrm{dX}$ \\
\hline Number of drugs in market & $\begin{array}{l}0.031 * * \\
(0.005)\end{array}$ & 0.0008 & $\begin{array}{l}0.028 * * \\
(0.007)\end{array}$ & 0.0008 & $\begin{array}{l}0.028 * * \\
(0.007)\end{array}$ & 0.0007 \\
\hline $\begin{array}{l}\text { Number of potential } \\
\text { entrants }\end{array}$ & $\begin{array}{l}-0.053 * * \\
(0.003)\end{array}$ & -0.0013 & $\begin{array}{c}0.005 \\
(0.004)\end{array}$ & 0.0001 & $\begin{array}{c}0.005 \\
(0.004)\end{array}$ & 0.0001 \\
\hline Population & $\begin{array}{l}-0.002 \\
(0.003)\end{array}$ & -0.0001 & $\begin{array}{l}0.062 * * \\
(0.018)\end{array}$ & 0.0016 & $\begin{array}{l}0.073 * * \\
(0.018)\end{array}$ & 0.0017 \\
\hline GDP per capita & $\begin{array}{l}0.046^{* *} \\
(0.005)\end{array}$ & 0.0013 & $\begin{array}{l}-0.002 \\
(0.013)\end{array}$ & -0.0001 & $\begin{array}{l}-0.021 \\
(0.014)\end{array}$ & -0.0005 \\
\hline Corruption score & $\begin{array}{l}-0.092 * * \\
(0.011)\end{array}$ & -0.0023 & $\begin{array}{l}-0.219 * * \\
(0.022)\end{array}$ & -0.0058 & $\begin{array}{l}-0.230 * * \\
(0.022)\end{array}$ & -0.0056 \\
\hline Market competition & $\begin{array}{l}-0.819 * * \\
(0.031)\end{array}$ & -0.0207 & $\begin{array}{l}-1.170 * * \\
(0.078)\end{array}$ & -0.0311 & $\begin{array}{l}-1.110 * * \\
(0.080)\end{array}$ & -0.0271 \\
\hline $\begin{array}{l}\text { Entry cost as percent of } \\
\text { GDP per capita }\end{array}$ & $\begin{array}{l}-1.780 * * \\
(0.121)\end{array}$ & -0.0450 & $\begin{array}{l}-3.470 * * \\
(0.232)\end{array}$ & -0.0921 & $\begin{array}{l}-3.660 * * \\
(0.237)\end{array}$ & -0.0893 \\
\hline Experience in country & $\begin{array}{l}0.054 * * \\
(0.003)\end{array}$ & 0.0013 & $\begin{array}{l}0.023 * * \\
(0.005)\end{array}$ & 0.0005 & $\begin{array}{l}0.023 * * \\
(0.005)\end{array}$ & 0.0005 \\
\hline Domestic firm & $\begin{array}{l}1.666^{* * *} \\
(0.050)\end{array}$ & 0.1200 & $\begin{array}{l}1.480 * * \\
(0.075)\end{array}$ & 0.1119 & $\begin{array}{l}1.474 * * \\
(0.075)\end{array}$ & 0.1017 \\
\hline International experience & $\begin{array}{l}0.009 * * \\
(0.002)\end{array}$ & 0.0003 & $\begin{array}{l}0.018^{* *} \\
(0.003)\end{array}$ & 0.0005 & $\begin{array}{l}0.018 * * \\
(0.003)\end{array}$ & 0.0005 \\
\hline Portfolio & $\begin{array}{l}-0.017 * * \\
(0.001)\end{array}$ & -0.0005 & $\begin{array}{l}-.012 * * \\
(0.002)\end{array}$ & -0.0003 & $\begin{array}{l}-0.012 * * \\
(0.002)\end{array}$ & -0.0002 \\
\hline Drug importance & $\begin{array}{l}0.836^{* *} \\
(0.178)\end{array}$ & 0.0212 & $\begin{array}{l}0.962 * * \\
(0.244)\end{array}$ & 0.0255 & $\begin{array}{l}0.974 * * \\
(0.243)\end{array}$ & 0.0237 \\
\hline $\begin{array}{l}\text { Number of countries } \\
\text { launched in }\end{array}$ & $\begin{array}{l}0.163 * * \\
(0.003)\end{array}$ & 0.0040 & $\begin{array}{l}0.158 * * \\
(0.005)\end{array}$ & 0.0042 & $\begin{array}{l}0.158 * * \\
(0.005)\end{array}$ & 0.0039 \\
\hline Price freeze & $\begin{array}{l}-0.201 * * \\
(0.037)\end{array}$ & -0.0144 & $\begin{array}{l}0.224 * * \\
(0.072)\end{array}$ & 0.0166 & $\begin{array}{c}0.092 \\
(0.079)\end{array}$ & 0.0062 \\
\hline Price controls & $\begin{array}{l}-0.324 * * \\
(0.028)\end{array}$ & -0.0230 & & & & \\
\hline $\begin{array}{l}\text { Firm headquartered in a } \\
\text { price-controlled country }\end{array}$ & $\begin{array}{l}-0.208 * * \\
(0.031)\end{array}$ & -0.0151 & $\begin{array}{l}-0.126^{* *} \\
(0.043)\end{array}$ & -0.0098 & $\begin{array}{l}-0.126^{* *} \\
(0.043)\end{array}$ & -0.0090 \\
\hline Supply-side controls & & & $\begin{array}{l}-0.418^{* *} \\
(0.093)\end{array}$ & -0.0318 & $\begin{array}{l}-0.452 * * \\
(0.095)\end{array}$ & -0.0311 \\
\hline
\end{tabular}


Prescribing budgets

\begin{tabular}{|c|c|c|c|}
\hline $\begin{array}{c}0.084 \\
(0.092)\end{array}$ & 0.0060 & $\begin{array}{l}-0.031 \\
(0.097)\end{array}$ & -0.0021 \\
\hline $\begin{array}{l}0.854 * * \\
(0.059)\end{array}$ & 0.0643 & $\begin{array}{l}0.871 * * \\
(0.059)\end{array}$ & 0.0602 \\
\hline $\begin{array}{l}-0.966 * * \\
(0.066)\end{array}$ & -0.0733 & $\begin{array}{l}-1.020 * * \\
(0.068)\end{array}$ & -0.0706 \\
\hline $\begin{array}{l}0.826^{* *} \\
(0.049)\end{array}$ & 0.0628 & $\begin{array}{l}0.825^{* *} \\
(0.049)\end{array}$ & 0.0567 \\
\hline $\begin{array}{l}0.188^{* *} \\
(0.047)\end{array}$ & 0.0144 & $\begin{array}{l}0.188^{* *} \\
(0.047)\end{array}$ & 0.0131 \\
\hline $\begin{array}{l}-0.068 * * \\
(0.010)\end{array}$ & -0.0019 & $\begin{array}{l}-0.069 * * \\
(0.010)\end{array}$ & -0.0017 \\
\hline & & $\begin{array}{c}0.054 * * \\
(0.013)\end{array}$ & 0.0035 \\
\hline \multicolumn{2}{|c|}{148531} & \multicolumn{2}{|c|}{148531} \\
\hline \multicolumn{2}{|c|}{-14728.1660} & \multicolumn{2}{|c|}{-14720.1088} \\
\hline
\end{tabular}

Therapeutic class reference pricing

Pharmacoeconomic evidence

Prior launch in a high price country

Prior launch in a low price country

Price rank

Price rank*post-1995

period

$*=5 \%$ significance, $* *=1 \%$. Marginal effects are computed at the mean of all independent variables for a 4 year old drug in 1997 in the antiarrythmics class; marginal effects for dummy variables represent the change from 0 to 1. All specifications include year and therapeutic class fixed effects. 
Figure 1: Distribution of the Number of Drugs in a Market

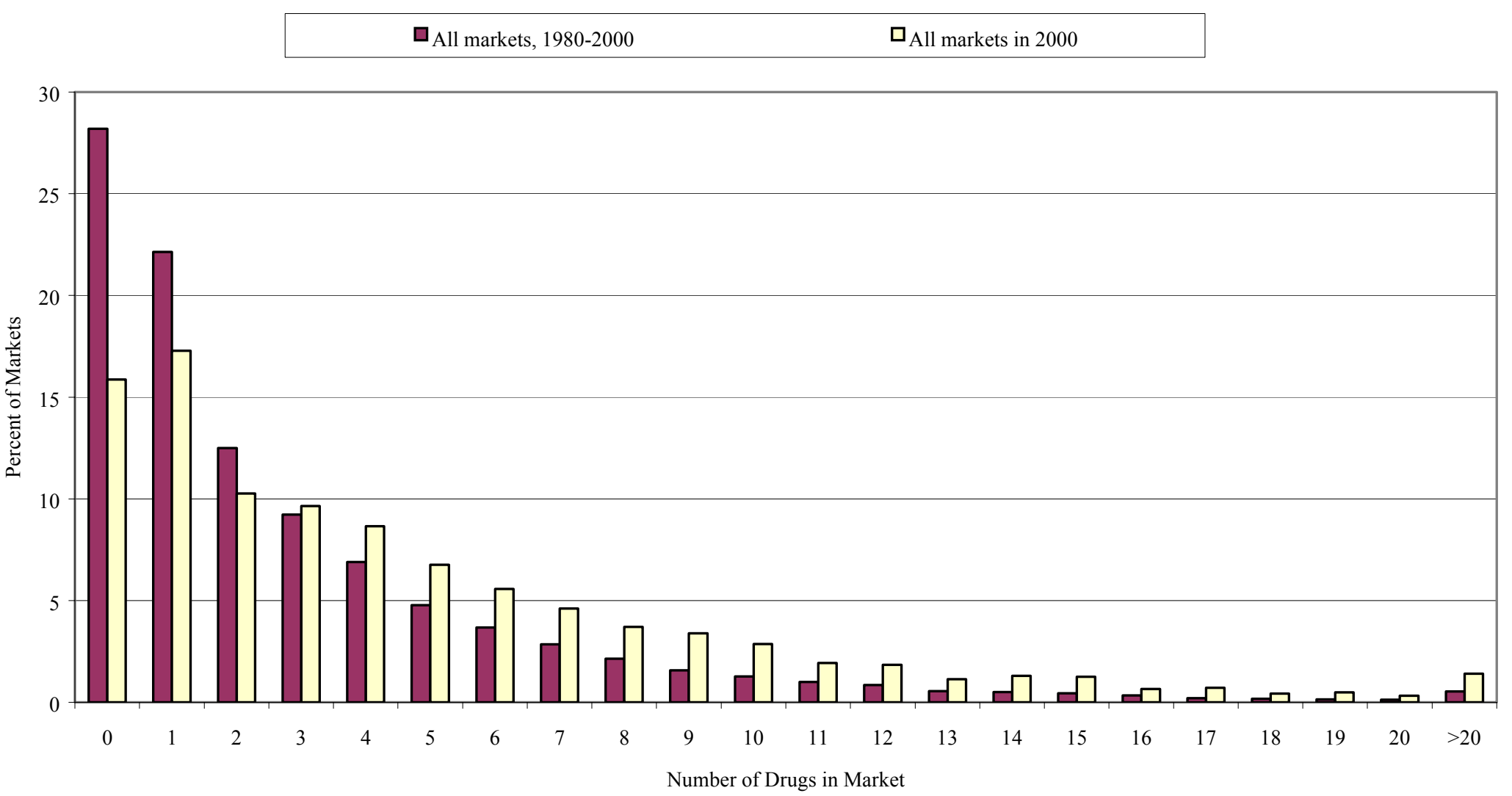


${ }^{1}$ Figures are annual totals for 2000. Source: IMS Health.

${ }^{2}$ Thomas et al. (1998), p. 790.

3 “Drug companies hit out at French price controls," Financial Times, June 10, 2001.

${ }^{4}$ See Jacobzone (2000) for a detailed summary of regulations in each country.

${ }^{5}$ Generic competition in the US is the focus of Caves et al. (1991) and Grabowski and Vernon (1992), among others. Hudson (2000) looks at the determinants of generic entry in the US, the UK, Germany, and Japan. Ellison et al. (1997) and Berndt et al. (1997) consider competition both within and between drugs.

${ }^{6}$ European Federation of Pharmaceutical Industries and Associations, "Barriers to Innovation in the Development of New Medicines in Europe and Possible Solutions to Address these Barriers"

${ }^{7}$ Financial Times, May 8, 2002, p. 21.

${ }^{8}$ Product quality is considered exogenous. Once a drug has been developed and tested, its efficacy is fixed: a firm cannot re-position a low-quality drug as a high-quality product. In reality, some "tweaking" is possible, such as once-a-day dosing formulations, but such changes are second order.

${ }^{9}$ See Amemiya (1985), pp. 433-455, or Allison (1984) for a more complete discussion of duration models.

${ }^{10}$ An obvious concern is that dangerous drugs may also have a high number of mentions. However, while a dangerous drug may have an increase in citations in 1-2 years before or after its withdrawal, its overall stock of citations in its therapeutic class does not seem to increase by much. The correlation between worldwide citations and a dummy variable indicating that a drug 
is eventually pulled from the market is -.038 , and the correlation between the "importance" measure and this dummy variable is -.042 .

${ }^{11}$ What these variables measure is unclear. A long life expectancy may indicate good health, but does this reflect low demand (healthy people don't need drugs, so little entry) or availability treatments (lots of entry)?

${ }^{12}$ This index can be downloaded from http://www.transparency.org/surveys/index.html.

${ }^{13}$ Negative binomial models were estimated because the data exhibited overdispersion, violating the assumption of equality of the mean and variance required for the Poisson.

${ }^{14}$ If these models are estimated using country-therapeutic class interaction fixed effects, the effect of competition on additional entry is negative. However, this specification does not permit consideration of regulatory effects. 